\title{
SMALLPOX INOCULATION AND DEMOGRAPHIC TRENDS IN EIGHTEENTH-CENTURY SCOTLAND
}

\author{
by \\ DEBORAH BRUNTON *
}

The impact of inoculation on levels of mortality has always been a contentious issue. Was the practice of deliberately infecting patients with a mild case of smallpox so as to produce immunity to further attacks the first of a triumphal succession of techniques by which medical men conquered infectious diseases, or a dangerous procedure of little or no value? Historically, opinions have swung back and forth. Eighteenth-century medical men and early demographers were convinced that it was the greatest medical improvement of the age. In 1782, John Howlett concluded that the increase in population he had observed in parish records was due "chiefly to that distinguished blessing of providence, inoculation". ${ }^{1}$ A number of early nineteenth-century writers, including Arthur Young and John Heysham, also attributed reduced mortality and rising population to the practice. ${ }^{2}$ By this time, however, inoculation was beginning to fall under a cloud, as proponents of vaccination sought to discredit the procedure, arguing that inoculated persons transmitted smallpox to the healthy and thus actually spread the disease.

In the twentieth century, historians and demographers have continued to debate the impact of inoculation on mortality. Initially, it was viewed unproblematically as one of an array of medical measures, including hospitals, dispensaries and new drugs, which contributed to increased life expectancy. ${ }^{3}$ In the 1960 s, however, conflicting interpretations were put forward and opinions remain divided. The thesis that inoculation had, at best, a minor effect on mortality levels was first stated by Thomas McKeown and R. G. Brown. They challenged the role of medicine in reducing death rates, pointing out that the greatest number of deaths was due to infectious diseases, which practitioners were powerless to treat. Inoculation was the sole exception

* Deborah Brunton, B.Sc., Ph.D., Science Studies Unit, University of Edinburgh, 21 Buccleuch Place, Edinburgh EG8 9LN

I would like to thank Prof. Michael Anderson, Dr John Henry, Dr Irvine Loudon, and Prof. Rosalind Mitchison for commenting on earlier drafts of this paper. Material from the Forfeited Estates Papers appears with the approval of the Keeper of Records of Scotland.

${ }^{1}$ J. R. Smith, The speckled monster. Smallpox in England, 1670-1970, with particular reference to Essex, Chelmsford, Essex Record Office, 1987, p. 60.

${ }^{2}$ Ibid., pp. 59-61; Peter Razzell, The conquest of smallpox. The impact of inoculation on smallpox mortality in eighteenth-century Britain, Firle, Sussex, Caliban Books, 1977, pp. 151-5.

${ }^{3}$ M. W. Flinn, British population growth, 1705-1850, Studies in Economic and Social History, London, Macmillan Press, 1970, pp. 40-2; E. A. Wrigley and R. S. Schofield, The population history of England 1541-1871, London, Edward Arnold, 1981, pp. 157-91. 


\section{Deborah Brunton}

to this rule, but a radical decrease in smallpox deaths - and they were far from certain that inoculation effected this-could not explain the magnitude of the reduction in mortality. ${ }^{4}$

The case for inoculation as a prime factor in falling mortality, and thus in population growth, has been put most forcefully by Peter Razzell. Re-examining eighteenthcentury data, he has argued that the procedure had a substantially lower mortality rate than that of natural smallpox and was widely practised. Although, when introduced in 1721 , inoculation was highly controversial and very expensive, which limited its use to the wealthiest classes, by the second half of the century it had acquired the universal approval of the medical profession, and improvements in techniques made it cheap enough to be within the means of all but the poorest ranks of society. Even the very poor were given access to the procedure through "mass" or "general" inoculations, paid for in England through the system of parochial Poor Relief. While conceding that inoculation was not fully accepted by the poor within urban areas, Razzell believed that by the last decade of the eighteenth century, "only a relatively small proportion of the population was left unprotected". 5 Thus a major killing disease had been controlled and a large number of deaths prevented. ${ }^{6}$ Razzell reinforced this argument by plotting a chronological correlation between the rise in the rate of population growth around 1760 and the growing popularity of inoculation. ${ }^{7}$ Razzell's broad conclusions have been widely repeated in demographic texts. ${ }^{8}$ In 1990 , his findings were supported by Alex Mercer in his Disease, mortality and population in transition. Mercer, too, emphasizes infectious disease, particularly smallpox, as the major cause of death in the early eighteenth century, but argues that the mortality crises associated with smallpox were checked by inoculation and fully controlled after the advent of vaccination. $^{9}$

Past criticism of Razzell's thesis has focused on his figures for smallpox mortality, which he claimed were under-recorded in burial records and that the true figure was around 20 per cent of all deaths. Several writers, most recently J. R. Smith, have suggested Razzell has seriously over-estimated smallpox mortality, and thus the effect of inoculation. Instead they propose that smallpox caused around 10 per cent or, at most, 15 per cent of all deaths. ${ }^{10}$ However, there has been no serious challenge to a central assumption of both Razzell's and Mercer's arguments - that inoculation was very widely practised. Razzell drew most of his data from records of public inoculation

\footnotetext{
${ }^{4}$ T. McKeown and R. G. Brown, 'Medical evidence related to English population changes in the eighteenth-century', in D. V. Glass and D.E.C. Eversley, Population in history, London, Edward Arnold, 1965, pp. 285-307, on p. 292; Thomas McKeown, The modern rise of population, London, Edward Arnold, 1976, pp. 107-8.

${ }^{5}$ P. E. Razzell, 'Population change in eighteenth-century England. A reinterpretation', Econ. Hist. Rev., 1965, 18: 312-32, p. 325.

${ }^{6}$ Razzell, op. cit., note 2 above, pp. 40-92, 101-12.

${ }^{7}$ Ibid., pp. 140-58.

${ }^{8}$ See, for example, Michael W. Flinn, The European demographic system 1500-1820, Brighton, Harvester Press, 1981, p. 98.

${ }^{9}$ Alex Mercer, Disease, mortality and population in transition. Epidemiological-demographic change in England since the eighteenth century as part of a global phenomenon, Leicester University Press, 1990, pp. 46-73.

${ }^{10}$ Smith, op. cit., note 1 above, p. 67.
} 


\section{Smallpox inoculation in eighteenth-century Scotland}

in the south of England, while Mercer uses long runs of statistics from parish records and bills of mortality for British towns and European countries. This paper re-examines the popularity of inoculation, and its impact on mortality using another source-the first Statistical account of Scotland.

Sir John Sinclair's Statistical account, compiled in the early 1790s, is a unique document. Under the sponsorship of the Church of Scotland, Sinclair sent questionnaires to the ministers of all 938 parishes in Scotland to obtain information on every aspect of life - social, economic, agricultural, religious-which might be of use in identifying and solving social problems. Kirk ministers were in a perfect position to record everyday life since they took an active role in the temporal as well as the spiritual affairs of their local communities, where the church acted as a welfare system as well as guiding the moral behaviour of parishoners. ${ }^{11}$ The replies varied in both length and content according to each minister's conscientiousness in fulfilling Sinclair's request and his desire to express his own grievances, opinions and interests. Material on inoculation came in response to question 93- "Are there any destructive epidemical diseases?" with almost 250 of Sinclair's correspondents referring to the practice as a means of controlling smallpox. ${ }^{12}$ Their accounts are particularly valuable since, unlike the parish records used by Razzell, they record not only organized schemes for public inoculation but also estimate the overall extent of inoculation within the whole community. Reports only occasionally give the numbers of persons inoculated; usually the ministers described the use of inoculation in qualitative terms, as "rare" or "general" or "universal", and many supplemented this with a wealth of anecdotal material on when and how it was introduced, which social groups were using the procedure and which were not, who performed the operation, and the opinions of ordinary people on inoculation.

Though it has been used in a number of contexts, this rich source of material has never been fully exploited to give an account of inoculation practice in Scotland. Razzell made a brief use of the Statistical account to estimate the popularity of inoculation in Scotland. He noted that its use varied over the country and concluded that the measure was less popular than in England, though he did not exempt Scotland from his claims for the impact of inoculation on population growth and presumably thought it was still substantially practised north of the border. ${ }^{13}$ Scottish historians and demographers have also described the uneven use of inoculation over the country, at its most popular in the Highlands and least used in the Western Lowlands, and the religious objections which retarded the practice. ${ }^{14}$ A. D. Farr

\footnotetext{
${ }^{11}$ Donald J. Withrington, 'General introduction', in Donald J. Withrington and Ian R. Grant (eds), The statistical account of Scotland, 21 vols., East Ardsley, Wakefield, E. P. Publishing, 1973-83, vol. 1, General, pp. ix-xlii, on p. xxiv; Callum Brown, The social history of religion in Scotland since 1730, London, Methuen, 1987, pp. 90-9.

${ }^{12}$ Sir John Sinclair, 'The history and origins and progress of the statistical account of Scotland', in Statistical account, vol. 1, General, pp. 22-130, on p. 44.

${ }_{13}$ Razzell, op. cit., note 2 above, pp. 95-7.

${ }^{14}$ Michael Flinn (ed.), Scottish population history from the 17th century to the 1930s, Cambridge University Press, 1977, pp. 291-2; T. C. Smout, A history of the Scottish people 1560-1830, Bungay, Suffolk, Fontana, 1973, pp. 254-6.
} 


\section{Deborah Brunton}

analysed the origins of this bias against inoculation as part of a larger study of religion and medicine. ${ }^{15}$

None of these works makes any systematic or detailed examination of either the interacting factors which determined whether or not communities chose to adopt inoculation or the distribution of inoculation across Scotland and its overall impact on levels of mortality. Careful examination of the Statistical account shows that its popularity was determined not just by religious or medical opinions but by perceived threats of smallpox, past experience of the disease, the costs of the practice and the availability of free inoculation. Using these reports as a representative sample of opinions - and the level of reporting is remarkably consistent over the country with between one-fourth and one-fifth of ministers in all but four counties commenting on the use of inoculation-it is possible to determine patterns of practice and to establish that in Scotland inoculation was too little practised to have more than a minimal effect on mortality. ${ }^{16}$ Although inoculation was in general use in a few areas, over the bulk of the country it was regularly used by only a small proportion of the population and did little to reduce the numbers of smallpox deaths.

\section{THE PRACTICE OF INOCULATION}

By the time Sinclair compiled his reports, inoculation had been practised in Britain for over seventy years. Initially it met with strong religious and medical disapproval. In spite of this-and a number of cases where the procedure produced severe smallpox or even death-it was embraced by the wealthiest classes, who could afford such a expensive procedure. Inoculation grew in popularity throughout the 1740s when the country was hit by severe smallpox. Opposition to it died away in the 1750s and it became a routine measure in the late 1760 s, as technical refinements made inoculation both safer and much cheaper. Although the procedure enjoyed the approval of the medical profession, it remained a contentious issue arousing fierce debates over techniques and the best methods of providing public inoculation. ${ }^{17}$

In Scotland the practice made rather slower progress after an inauspicious start in 1726 when one of the first ten children to be inoculated died shortly after the operation. ${ }^{18}$ The practice was not revived until 1733 and thereafter gradually spread over the country. It was still far from popular in 1765 when Alexander Monro primus, professor of anatomy at the Edinburgh Medical School, made a survey of inoculation among the medical profession. Only 88 practitioners-around a third of Scotland's medical men-had taken up the procedure and had inoculated a total of 5,554 people. ${ }^{19}$ Reports in the Statistical account suggest that inoculation was introduced to many areas in the 1770 s and 1780 s and reached a peak of popularity in the 1790 s.

${ }^{15}$ A. D. Farr, 'Medical developments and religious belief with special reference to Europe in the eighteenth and nineteenth centuries', Ph.D. thesis, Open University, 1977, pp. 65-77.

${ }_{16}$ The exceptions were Morayshire, Wigtownshire, East Lothian and Midlothian.

${ }^{17}$ Deborah C. Brunton, 'Pox Britannica: smallpox inoculation in Britain, 1721-1830', Ph.D. thesis, University of Pennsylvania, 1990.

18 James Jurin, Account of the success of inoculating for the small pox in Great Britain, for the year 1726, London, J. Peele, 1727, pp. 19, 22-3.

${ }_{19}$ Alexander Monro, An account of inoculation of the small pox in Scotland, Edinburgh, Drummond and J. Balfour, 1765, pp. 27-9. 


\section{Smallpox inoculation in eighteenth-century Scotland}

Eighteenth-century inoculation was a far cry from the modern routine of immunization. Rather than inoculate children at a set age, the procedure was performed in short, erratic bursts whenever smallpox appeared in the locality. In part, this was a question of logistics. Normally, the infective matter used to transmit the disease was taken directly from a smallpox victim-preferably, but not necessarily, suffering a mild case-or from a recently inoculated patient. This was possible only when smallpox was present within the immediate area. It was feasible to inoculate at other times by transporting matter from elsewhere, or by using preserved matter, though practitioners found this less satisfactory as it occasionally failed to induce the disease. In practice, inoculation was rarely performed unless there was a real risk of catching smallpox - it made little sense to infect healthy patients with a dangerous disease which inevitably caused some fatalities, unless there was a chance of catching an even more dangerous case of natural smallpox.

Scottish people seemed reluctant to begin inoculating, waiting until a number of deaths convinced them of the destructive capacity of an outbreak, though few were so tardy as the inhabitants of Newburgh, Fife, who did not begin inoculating until 56 children had died in an epidemic in $1791 .^{20}$ Once the procedure had begun, inoculation was intensively practised. In the parish of Buchanan, Stirlingshire, for example.

The disease spreading fast, about 30 of the young people in the neighbourhood where it was, took it; 10 of whom died. All the parents whose children had not taken it, (two or three excepted), as if it were with one consent, inoculated their children at one and the same time so that there are just now under inoculation in this parish $128 .^{21}$

When an outbreak had ended, however, inoculation lapsed for long periods. One minister noted that, "Inoculation has been practised here, and many submitted to it thankfully, when strongly recommended to them some years ago; but for some time past it seems to have been forgotten". 22

Though the timing of inoculation was determined by smallpox epidemiology, exactly who adopted the procedure was influenced by a complex set of factors. Attitudes differed sharply according to social class. The wealthy and educated saw inoculation as beneficial and willingly took it up. In his 1765 survey, Monro had noted that while "the greater numbers of the gentry, and most of the medical gentlemen" inoculated their children, the lower classes refused to do so. ${ }^{23}$ Thirty years later this was still the case. Ministers all over Scotland echoed the observations that inoculation "has never been practised here, but by the gentlemen", or that inoculation had been adopted "among the most respectable families". ${ }^{24}$ The ministers themselves often took the lead and were the first to have their children inoculated. A few even performed the

20 Statistical account, vol. 17, Applecross, p. 291, Dingwall, p. 355; vol. 10, Newburgh, p. 664.

21 Statistical account, vol. 9, Buchanan, p. 195.

22 Statistical account, vol. 11, Longforgan, p. 345.

23 Monro, op. cit., note 19 above, p. 6.

24 Statistical account, vol. 17, Kilmuir Wester and Suddy, p. 450n; vol. 13, Linthrathen, p. 419. See also vol. 17, Urray, p. 678n; vol. 9, Clackmannan, p. 713. 


\section{Deborah Brunton}

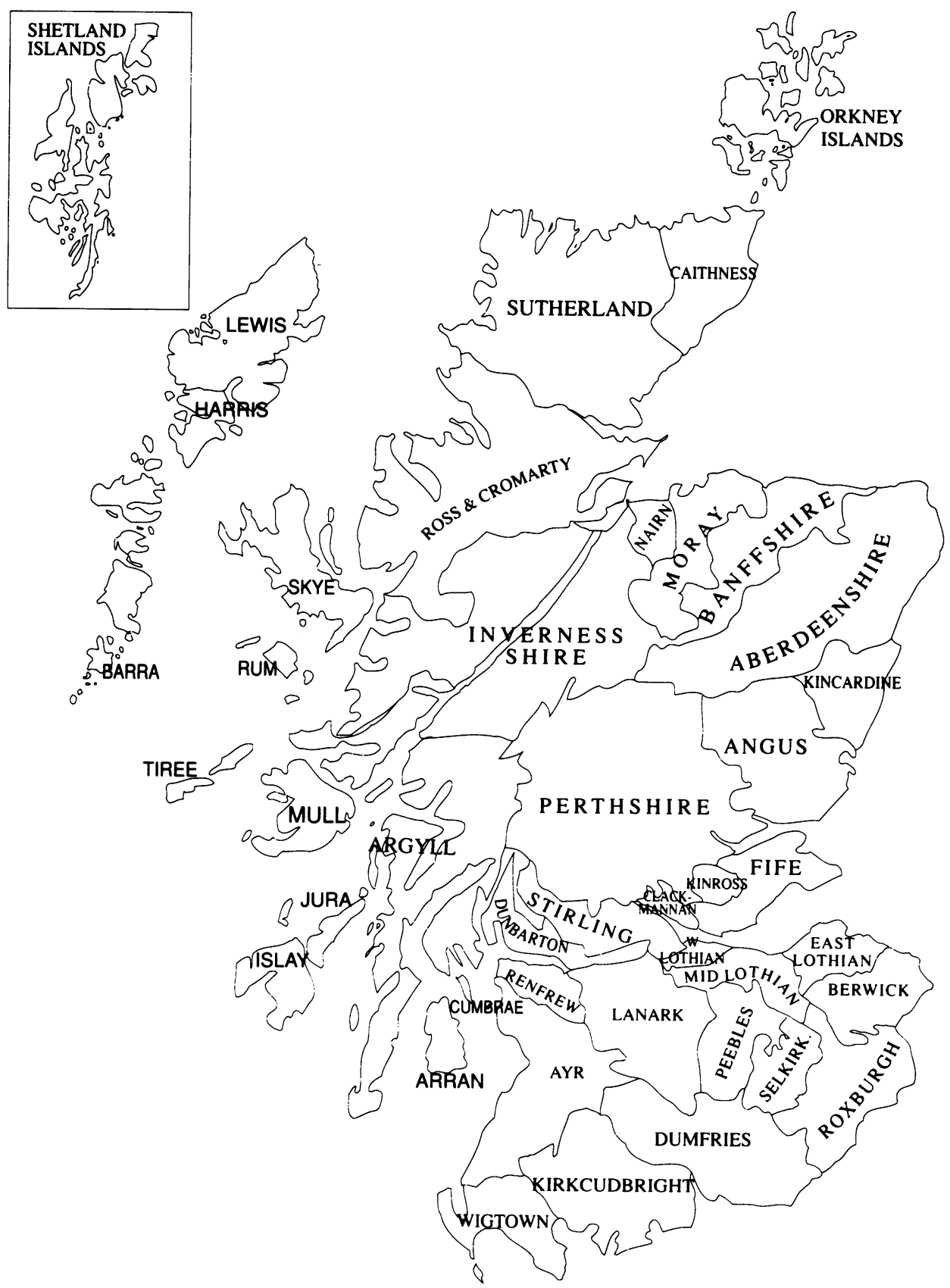

Map 1: Map of Scotland taken from John Thomson's Atlas of Scotland of 1832 showing the approximate position of the county boundaries in the 1790 s. 


\section{Smallpox inoculation in eighteenth-century Scotland}

operation on their own families. ${ }^{25}$ The bulk of the population-the "lower orders"were still cautious about accepting inoculation. In a very few areas it had come into general use, but over large parts of the country it was rarely, if ever, practised by any except the gentry.

One of the most important factors encouraging the adoption of inoculation by the lower classes was high, long-term smallpox mortality. Smallpox displayed two distinctive epidemiological patterns in Scotland. In isolated communities, such as the islands, it showed the characteristics of epidemic disease, sweeping through communities infrequently and causing high mortality, then disappearing for several years. In the eighteenth century, island populations were repeatedly decimated. St Kilda, the most remote of the inhabited Scottish islands, "was very near stript of all its Inhabitants" when hit by smallpox for the first time. ${ }^{26}$ One minister, writing in the Statistical account, recalled the horror of an epidemic on the Shetland island of Foula where "only a few persons were left, to perform the last office of humanity to their brethren". ${ }^{27}$ Barra in the Outer Hebrides and even Tiree in the Inner Hebrides, which was relatively close to the mainland, lost around one-fifteenth of their total populations in single outbreaks. ${ }^{28}$ This high mortality correlates with a widespread use of inoculation in these northerly Scottish islands, where the practice had become popular at every social level. In Shetland, it was practised by "all ranks" in Lerwick; was "perfectly general" in Northmavine; while in Unst it had been "general" for thirty years. Similarly, inoculation was "general" in North Uist and universally used in five of the seven parishes on Skye. ${ }^{29}$

The epidemiological pattern of smallpox on the islands was not dissimilar to that found on the English mainland, where discrete, densely populated village communities were periodically visited by the disease. In mainland Scotland, however, smallpox showed a quite different incidence. Much of the Scottish rural population was scattered thinly over the countryside in small settlements, called "farm touns", consisting of a few families. As a result, infectious diseases travelled through areas very slowly and were present for long periods. In some parishes, smallpox deaths were recorded in five, or even eight, of ten years, though more typically it was present for around one-third of the time. ${ }^{30}$ In most years smallpox claimed only a few victims, but periodically the death rate jumped to epidemic proportions.

Though patterns of smallpox epidemiology were uniform over the mainland, there were marked dissimilarities in the mortality levels of different outbreaks. The minister of Fenwick, Ayrshire, described how a smallpox epidemic had spread "through every corner" of the parish and attacked a large number of people, but it resulted in only

\footnotetext{
${ }^{25}$ Statistical account, vol. 13, Auchterhouse, p. 51n; vol. 9, Old Kirkpatrick, p. 71.

${ }^{26}$ Margaret Mackay (ed.), The Reverend John Walker's report on the Hebrides of 1764 and 1771, Edinburgh, John Donald, 1980, p. 59.

${ }^{27}$ Statistical account, vol. 19, Walls and Sandness, p. 521.

28 Walker, op. cit., note 26 above, pp. 86, 183.

29 Statistical account, vol. 19, Lerwick, p. 441, Northmavine, p. 469, Unst, p. 513; vol. 20, North Uist, p. 112, Duirinish, p. 161, Kilmuir, p. 170, Portree, p. 194, Snizort, p. 215, Strath, p. 224.

30 Statistical account, vol. 9, Kilsyth, p. 467; vol. 10, Carnock, p. 118; vol. 14, Benholme, p. 40; vol. 6, Irvine, p. 247; Rosalind Mitchison, 'Death in Tranent 1754-81', Transactions of the East Lothian Antiquarian and Field Naturalist Society, 1979, 16: 37-48, p. 42.
} 


\section{Deborah Brunton}

three deaths. Similarly, in Carnock, Fife, between 1780 and 1783 "many cases" of smallpox produced four to six deaths each year, but in 1787 one-third of victims died. ${ }^{31}$ Mortality rates for particularly severe epidemics could be even higher; instances were reported of 13 survivors from 32 cases, and 13 cases of which only 1 survived. ${ }^{32}$ In these epidemic years, smallpox accounted for a third or more of all deaths. In Peterhead, 27 of 72 burials and 34 of 86 were attributed to smallpoxroughly 37 per cent and 39 per cent respectively. The disease accounted for 40 per cent of all deaths in Kilsyth in 1792, while in the parish of Tarbat, Inverness-shire, some families lost all their children to smallpox. ${ }^{33}$

Historians and demographers usually assume that although the number of deaths varied from year to year, in the long term smallpox caused relatively uniform levels of mortality, around 10 per cent of all deaths. Variations in the overall mortality from as low as 6 per cent to as high as 20 per cent have been attributed to inconsistencies in burial records. Scottish legislation requiring death records was largely ignored, with the burials of small children and infants seriously under-recorded. ${ }^{34}$ However, reports in the Statistical account, which usually reflected the ministers' personal experiences and could be expected to show a more accurate picture, suggest that the impact of smallpox varied quite dramatically from place to place. In many Scottish parishes, smallpox was undoubtedly one of the most feared and destructive diseases. Ministers described it as one of the three or four most fatal, which attacked virtually all children at some time and killed a large proportion. At its most severe, as in the parish of Cluny, it reportedly carried off one-fifth of the population. ${ }^{35}$

However, a small but significant number of reports, scattered over the country, claimed that smallpox was mild and caused few deaths. In Galashiels, though the disease had visited frequently in the previous twenty years, it was "never general or violent"; in Bothwell, Lanark, it was "seldom fatal"; while in the parishes of Canisbay, Peterculter and Banchory-Tarnan it was "seldom mortal". The ministers of Kirkcaldy and Symington believed that smallpox was milder in their parishes than in the surrounding area. ${ }^{36}$ These reports did not refer to particular freak years. One minister recorded only eight smallpox deaths in nineteen years and, perhaps most remarkable of all, in Cathkin, in the parish of Carmunnock, no one had died from smallpox for the past twenty-four years, though the parish had been hit by six epidemics. ${ }^{37} \mathrm{~A}$ reduction in smallpox deaths may have been a recent phenomenon; several ministers attributed better survival rates among sufferers to the fact that their parishoners abandoned the old "hot method" of treatment. Rather than make

${ }^{31}$ Statistical account, vol. 6, Fenwick, p. 200; vol. 10, Carnock, p. 118.

${ }^{32}$ Statistical account, vol. 17, Applecross, p. 291; vol. 7, East Kilbride, p. 414.

33 Statistical account, vol. 15, Peterhead, p. 410; vol. 9, Kilsyth, p. 467; vol. 17, Tarbat, pp. 645-6.

${ }^{34}$ Smallpox caused 5 or 6 per cent of deaths in Cleish, Kettins and Fordoun, but 16 per cent of all deaths in Tranent, Kilmarnock and Cathcart. See the Old Parochial Records, Scottish Record Office, Cleish, 1745-1789, 460/1, Kettins, 1751-1806, 294/5, Fordoun, 1791-1819, 259/4, Kilmarnock, 1728-1763, 597/6, Cathcart, 1746-1815, 560/1. The Tranent records are analysed in Mitchison, op. cit., note 30 above, pp. $42-3$.

${ }^{35}$ Statistical account, vol. 19, Mid and South Yell, p. 542; vol. 14, Cluny, p. 439.

${ }^{36}$ Statistical account, vol. 4, Galashiels, p. 668; vol. 7, Bothwell, p. 34; vol. 18, Canisbay, p. 12; vol. 14, Peterculter, p. 642, Banchory-Tarnan, p. 26; vol. 10, Kirkcaldy, p. 511; vol. 6, Symington, p. 634.

${ }^{37}$ Statistical account, vol. 16, Botriphnie, p. 105; vol. 7, Carmunnock, p. 172. 


\section{Smallpox inoculation in eighteenth-century Scotland}

patients sweat by wrapping them in blankets, placing them in front of a fire and plying them with whisky to "force out" the pocks, they adopted Thomas Sydenham's more successful "cool method", in which the fever was treated with cold drinks and fresh air. ${ }^{38}$

As on the islands, inoculation was most popular where there was high smallpox mortality. Serious epidemics were often the inspiration for the introduction of inoculation, and, as we have seen, the procedure was most frequently performed during smallpox outbreaks. ${ }^{39}$ Long-term high death rates from smallpox in the Borders may have encouraged the adoption of inoculation in Eccles-where reputedly one-third of cases died-Jedburgh and Southdean. Ministers in Tongue in Sutherland, Cluny in Aberdeenshire and Kilninver in Argyll also complained of the ravages of smallpox before the introduction of inoculation. ${ }^{40}$ Equally, where smallpox caused few deaths, and therefore offered little threat to life, the population saw no need for inoculation. In Marykirk, where "very few children die of the small pox", attempts to introduce the practice had failed. ${ }^{41}$ The Galashiels minister explained that his congregation were slow to adopt it, but "the mildness of the natural small-pox, makes its progress slower than it otherwise might be". ${ }^{42}$ In Tillicoultry, Clackmannan, the minister observed, "Many children took the small pox, last year, in the natural way, only one of whom died ... Were the small-pox to be always equally favourable, inoculation would fall into disuse". ${ }^{43}$

A second factor predisposing the Scottish population to take up the practice was access to free inoculation. The procedure had gradually become cheaper over time but in the 1790s a Banffshire surgeon still charged from two guineas to five shillings using a sliding scale according to his patients' ability to pay. This still put inoculation well beyond the means of a large part of the population. As the minister of Aberdour pointed out, "A workman, with a small family, hath very little to spare to the surgeon". ${ }^{44}$ The poor in Scotland could not turn to the Poor Law as a source of free inoculation as did their English counterparts. The organization of poor relief in Scotland was less well adapted to the provision of public inoculation. English parish funds were generally larger with regular levies on wealthier members of the community. When threatened by smallpox, the parish authorities could rapidly draw on these funds to finance a general inoculation. Scottish Poor Law funds were much smaller, collected through voluntary contributions at the kirk door and occasional demands on the wealthier members of the community in times of exceptional need. ${ }^{45}$ The scattered population also made mass inoculations both expensive and difficult to

${ }^{38}$ Statistical account, vol. 18, Dornoch, p. 360; vol. 15, Montquitter, p. 321; vol. 9, Clackmannan, p. 713; vol. 16, Cullen, p. 122, Dyke and Moy, p. 538.

${ }^{39}$ Statistical account, vol. 17, Dingwall, p. 355, Cromarty, pp. 338-9.

40 Statistical account, vol. 3, Eccles, p. 155, Jedburgh, p. 486, Southdean, p. 641; vol. 18, Tongue, p. 480; vol. 14, Cluny, p. 439; vol. 8, Kilninver, p. 284n.

${ }_{41}^{4}$ Statistical account, vol. 7, Wiston and Roberton, p. 611; vol. 14, Marykirk, p. 185.

${ }^{42}$ Statistical account, vol. 4, Galashiels, p. 688.

${ }^{43}$ Statistical account, vol. 9, Tillicoultry, p. 781.

44 Statistical account, vol. 16, Banff, p. 45n; vol. 10, Aberdour, p. 25.

45 Razzell, op. cit., note 2 above, pp. 83-92; Smith, op. cit., note 1 above, pp. 47-54; R. A. Cage, The Scottish Poor Law 1745-1845, Edinburgh, Scottish Academic Press, 1981, pp. 1-18 and personal communication from Prof. Michael Anderson. I am very grateful for his guidance on this matter. 


\section{Deborah Brunton}

organize. Detailed records of two general inoculations conducted in 1775 and 1780 show how travelling expenses pushed up the cost of the scheme, with practitioners travelling up to six or even ten miles to inoculate. The distances between settlements also meant that general inoculations were long drawn out affairs-in Crieff it took ten months to inoculate less than 200 children. ${ }^{46}$

The Statistical account contains only one record of a general inoculation which may have been paid through poor relief. In 1783, faced by a second failed harvest and the first smallpox epidemic in a number of years, the kirk session of Kirkwall in the Orkney islands "agreed to bear the expence [sic]" of inoculating poor children. The scheme was hardly over-subscribed-less than 40 persons were inoculated from a total population of around 2,500, but the number of candidates was reduced by earlier extensive use of inoculation. ${ }^{47}$

Although it would appear from this that the inoculation was carried out through poor relief, in fact, as in the case of other Scottish general inoculations, the system of making special collections for specific purposes may have been informally used. In spite of the fact that the ministers and elders actually organized general inoculations, they were not officially part of the poor relief system. Typically, ministers and their kirk sessions persuaded one or more of the local "heritors"-landowners obliged to contribute to kirk funds - to pay for the inoculation of the parish poor. They then undertook the practical arrangements, employing a medical man and setting dates, and used their powerful position in the community to promote the event and generally lend their considerable weight to the undertaking. ${ }^{48}$ Sometimes, the chief landowner was approached, so that in Roxburgh the Honourable Baron Rutherford agreed to foot the bill for inoculation; elsewhere, as in Eccles or Durness, a group of heritors jointly put forward the necessary funds. The heritors of Jedburgh were less generous - they provided a "small sum" to subsidize the costs of inoculation for poor families ${ }^{49}$ Less frequently, large landowners, like Lord Douglas and the owner of the estates in Muthill parish, organized similar schemes without the help of the kirk, employing a physician or surgeon to inoculate poor tenants. ${ }^{50}$

Compared to the large, highly organized mass inoculations in England, those in Scotland must have been much less effective in controlling smallpox. Such programmes were not common; five were reported in the prosperous southern counties of Berwickshire and Roxburghshire, and three more in Aberdeenshire, Perthshire and Sutherland. ${ }^{51}$ Most were one-off affairs-only in Muthill was the offer repeated-and relatively few participated. The largest number recorded as having been inoculated were 70 children in Earlston. However, the minister reported that the scheme had a wider effect, encouraging use of the procedure by demonstrating its

\footnotetext{
${ }^{46}$ Andrew Murray, Letters and Journal, Crieff, 1775, Perth Estate, E 777/14/6; John McLagan, Letters on inoculation to William Barclay, Taymouth, 1780, Struan Estate, E 788/11; both in Forfeited Estates Papers, Particular Management, Scottish Record Office, Edinburgh.

${ }_{47}^{4}$ Statistical account, vol. 19, Kirkwall and St Ola, pp. 143-4; Scot's magazine, 1757, 19: 75.

48 Statistical account, vol. 13, Dunnichen, p. 210.

${ }^{49}$ Statistical account, vol. 3, Roxburgh, p. 624, Eccles, pp. 155-6, Jedburgh, p. 486; vol. 18, Durness, p. 378.

${ }^{50}$ Statistical account, vol. 3, Southdean, p. 641; vol. 12, Muthill, p. 784.

${ }^{51}$ Statistical account, vol. 3, Roxburgh, p. 624, Eccles, pp. 155-6, Earlston, p. 145; vol. 14, Towie, p. 735; vol. 18, Durness, p. 378.
} 


\section{Smallpox inoculation in eighteenth-century Scotland}

safety and so it was "more generally practised" afterwards. ${ }^{52}$ In Eccles, too, the public inoculation of poor children did "more to promote the practice, than either reason or eloquence could have effected". 53

Free inoculation was more commonly obtained through the goodwill of both formally trained and lay practitioners. In 1791 and again in 1792 the Royal College of Physicians, Edinburgh, advertised in the Caledonian Mercury that any poor person applying to one of their members during September or October would be inoculated gratis. ${ }^{54}$ Individual practitioners also mounted inoculation campaigns. John Williamson, a public-spirited Caithness surgeon, travelled the county inoculating over 600 children, while in the parishes of Deer and Auchindoir in Aberdeenshire, and Gargunnock in Stirlingshire local practitioners inoculated poor families free of charge. ${ }^{55}$ Irregular practitioners were a more significant source of free inoculation. An impoverished and largely rural country, Scotland was poorly supplied with medical men, and lay inoculators, drawn from a curious mixture of backgrounds, stepped in to fill the gap. Members of the upper classes and church ministers, who traditionally offered ex-officio medical care, took up inoculation; in Shetland a "young gentleman" carried out 132 and 200 inoculations, while in Sutherland a gentlewoman - the only female inoculator mentioned in the Statistical accountinoculated 99 people. ${ }^{56}$ Ministers too had substantial practices among their congregations. The incumbent of Kirkcudbright inoculated 90 people while William Mitchell, the minister of Tingwall

Finding that the common people declined to inoculate their children in consequence of the expense attending it when a regular surgeon was employed, resolved to undertake it himself, without charging them anything, and carried it on with great success, having inoculated no less a number than 950 , between the years 1774 and $1793 .^{57}$

Several ministers used the Statistical account to propose that divinity students be taught to inoculate as part of their training, while another believed that such a plan was already in operation at Edinburgh University. ${ }^{58}$ Yet another suggested that the Society for the Propagation of Christian Knowledge, which ran free schools, should arrange for their schoolmasters to be trained in inoculation. There was no doubt that the task was within their capabilities; after all, "If the women inoculate in the east, (as we are told they do), schoolmasters certainly might, with very few lessons, be taught to do it here". 59

52 Statistical account, vol. 3, Earlston, p. 145.

53 Ibid., Eccles, pp. 155-6.

${ }^{54}$ Minutes of the Royal College of Physicians, Edinburgh, 2 August 1791, 7 August 1792; Caledonian Mercury, Saturday, 3 September 1791, Saturday, 1 September 1792.

55 Statistical account, vol. 18, Thurso, pp. 169-70; vol. 15, Deer, p. 100, Auchindoir p. 20n; vol. 9, Gargunnock, p. 371.

56 Statistical account, vol. 19, Aithsting and Sandsting, p. 390, Bressay, Burra and Quarff, p. 392; vol. 18, Tongue, p. 480.

${ }^{5}$ Statistical account, vol. 5, Kirkgunzeon, p. 221, New Abbey, p. 280, Kirkpatrick-Irongray, p. 252; vol. 19, Tingwall, p. 480; vol. 9, Old Kirkpatrick, p. 71.

58 Statistical account, vol. 5, New Abbey, p. 280n; vol. 19, Tingwall, p. 480; vol. 12, Callander, p. 188.

59 Statistical account, vol. 12, Callander, p. 188. 


\section{Deborah Brunton}

Lay inoculators also came of humble origins, such as the "common blood-letter", the "square wright" (a carpenter or cabinetmaker), the "man, in no respect noted for acquired knowledge" or the "common men, who pretended to no skill, and gave no medicines". ${ }^{60}$ The square wright had "the generosity to practise gratis" and, judging by the large numbers inoculated by other irregular practitioners, they probably charged very little, if anything - several had inoculated over 100, and one performed 700 inoculations. ${ }^{61}$ Some took their practice very seriously. On Mid Yell, in the Shetland islands, a local jack-of-all trades, John Williamson, developed his own idiosyncratic technique, preparing the infective matter by drying it over peat smoke, then burying it for seven or eight years to lessen its virulence. Although strange, the method reportedly proved successful in "several thousand" inoculations. ${ }^{62}$ There was little animosity between lay and regular practitioners, who worked in close cooperation. During a severe epidemic in Aithsting and Sandsting, 327 people were inoculated by a local physician, another 200 by a "gentleman", and around 100 by "common men"; all of whom were then cared for by the physician. ${ }^{63}$

Some parents who could find no inoculator willing to practise gratis, or simply wished to save expense, inoculated their own children. In a few cases, parents received help —in Leuchars, they were "supplied with a lancet covered in matter"-but mostly they performed the operation unassisted. ${ }^{64}$ Although most common in remote areas where medical help was unavailable, inoculation by parents was also recorded in Fife and Renfrewshire, which were well supplied with practitioners. In general, their efforts seem to have been successful, although on the island of Harris, a number of children inoculated at home subsequently caught smallpox, to the puzzlement of the minister, who assured his readers that previously this "was found to have answered ... without any fatal consequences". ${ }^{65}$

Obviously, although cost was a factor in deciding whether or not to have children inoculated, it was not the most important consideration. Where free inoculation was available, it clearly encouraged the adoption of the practice. However, the expense was not an insurmountable obstacle. Parents could and did inoculate their own children, and in many parishes the practice proved popular even though there was no reported mechanism to provide free inoculation. Cost may have prevented relatively few parents from having their children inoculated. In the whole Statistical account only five ministers complained that their congregations could not afford to inoculate. $^{66}$

Religious and moral objections had a much more important influence on the popularity of inoculation among the lower classes. The potential moral dilemmas if a

${ }^{60}$ Statistical account, vol. 17, Inverness, p. 83-4, Applecross, p. 29; vol. 19, Aithsting and Sandsting, p. 389 ; vol. 5 , Kirkpatrick-Irongray, p. 252.

${ }_{61}$ Statistical account, vol. 17, Inverness, p. 83-4, Applecross, p. 29; vol. 19, Aithsting and Sandsting, p. 389.

62 Statistical account, vol. 19, Mid and South Yell, pp. 542-3.

${ }^{63}$ Ibid., Aithsting and Sandsting, pp. 389-90.

${ }^{64}$ Statistical account, vol. 20, North Uist, p. 112; vol. 7, Renfrew, p. 864; vol. 3, Peebles, p. 873; vol. 10, Leuchers, p. 615; vol. 13, Auchterhouse, p. $51 \mathrm{n}$.

${ }^{65}$ Statistical account, vol. 20, Harris, p. 92.

${ }^{66}$ Statistical account, vol. 7, Renfrew, p. 864; vol. 10, Crail, p. 173; vol. 14, Strathdon, p. 706; vol. 18, Rogart, p. 469; vol. 20, Jura and Colonsay, p. 371. 


\section{Smallpox inoculation in eighteenth-century Scotland}

child died as the result of inoculation were obvious; and some people stated they "would consider themselves guilty of a species of murder, if the event should prove fatal" ${ }^{67}$ Religious objections to the practice were rooted in a belief in predestination, which held that

all diseases which afflict the human frame are instances of the Divine interposition, for the punishment of sin; any interference, therefore, [is] an usurpation of the prerogative of the Almighty. ${ }^{68}$

In this scheme inoculation interfered with the action of Providence.

We tempt GOD ... by voluntarily bringing on a disease which we might possibly have escaped: We throw ourselves in the way of danger: We distrust the Providence of Almighty GOD, who is all-sufficient to deliver us. ${ }^{69}$

Such religious objections prevailed in the poorer sections of society. The richer, better-educated members of the population, including the clergy of the Church of Scotland, subscribed to a moderate Enlightenment theology which valued inoculation as a measure for the benefit of the individual and the good of society as a whole. ${ }^{70}$ Belief in predestination is usually associated with the Scottish secession churches and, certainly, seceders were often singled out for their objections to inoculation. ${ }^{71}$ In Castleton and Bowden in the Borders, for example, seceders refused to adopt the practice although it was popular among the rest of the population. ${ }^{72}$ However, such views were also widely held among Church of Scotland congregations, particularly in those areas where the secession churches drew their strongest support. ${ }^{73}$

This sharp division of opinion between the pro-inoculation ministers and their anti-inoculation congregations provoked some of the most vivid prose in the Statistical account. Ministers graphically recorded the depths of feeling against the practice. When one Aberdeenshire family was successfully inoculated, "so violent were the prejudices of the people, that ... some of [the inhabitants] declared, if the inoculated children had died, they would have considered it as a just dispensation of Providence". ${ }^{74}$ The ministers' exasperation at this rejection of inoculation also comes over clearly. The minster of East Kilbride raged, "Rooted prejudices, founded upon arguments, some of which are trifling, and others absurd, influence the people so much against it, that they sit still, in sullen contentment, and see their children cut off

\footnotetext{
67 Statistical account, vol. 9, Clackmannan, p. 713.

${ }^{68}$ Statistical account, vol. 16, Auldearn, p. 718.

69 Ibid., Banff, p. 44.

${ }^{70}$ Richard Sher, Church and university in the Scottish Enlightenment. The moderate literati of Edinburgh, Edinburgh University Press, 1985. For a more general view of eighteenth-century improving morals see John Dwyer, Virtuous discourse: sensibility and community in late eighteenth century Scotland, Edinburgh, John Donald, 1987.

${ }^{71}$ Farr, op. cit., note 15 above, pp. 12-16; D. W. Bebbington, Evangelicalism in modern Britain. A history from the 1730s to the 1980s, London, Unwin Hyman, 1989, pp. 55-7.

72 Statistical account, vol. 3, Bowden, p. 375, Castleton, p. 384.

${ }^{73}$ Reid Stewart, 'The development of the voluntary principle and practice in Scotland', Ph.D. thesis, Edinburgh University, 1976, pp. 136-76, 322-8.

${ }^{74}$ Statistical account, vol. 14, Tough, p. 730.
} 
in multitudes". ${ }^{75}$ While the minister of Carmunnock angrily reported that "the people from a sort of blind fatality, will not hear of inoculation". ${ }^{76}$

The clergy struggled long and hard to persuade their congregations of the error of their ways. They used the pages of the Statistical account to rehearse theological arguments in favour of inoculation, pointing out that it was no different from any other form of medical treatment:

Does not the man, for instance, equally tempt GOD, who, apprehending a mortification in one of his limbs, submits to lose it by the operation of a surgeon. Perhaps the dreaded mortification might not have taken place, and the patient sacrifices his life to his timid caution. Yet no man of common sense will dispute, that the practice of amputation is salutary on the whole, and is the means of preserving many valuable lives to the community. ${ }^{.7}$

Other ministers argued that God had given men the knowledge of inoculation, and therefore it was a religious duty to practise it "as an expression of their thankfulness to God for so gracious a discovery" ${ }^{78}$ Several resorted to the compelling logic of statistics; since the chances of dying from inoculated smallpox were far less than for the natural disease, it was obviously better to take the lesser risks associated with inoculation. $^{79}$

They made little headway. One minister lamented that "the people ... seem deaf to all arguments used to show its lawfulness and expediency". 80 Another wrote despairingly, "it is well known, at least to the clergy, that every argument in support of inoculation, however conclusive or self-evident, makes no impression upon their minds" ${ }^{81}$ Even the efforts of the energetic minister of Auchterhouse had little effect. He

argued with [his congregation] in private, and recommended inoculation from the pulpit. He told them, that many of the most pious and popular clergymen had adopted the scheme in their own families; and that, from the great success that attended it in every quarter of the globe, there was good reason to conclude, that it was a scheme highly favoured by Providence. ${ }^{82}$

All to no avail. "Their prejudices remained, and their children continued to die." 83

Although many congregations stubbornly refused to accept inoculation, the Ayrshire minister who gloomily pronounced that "this impious presumption, these illiberal and groundless prejudices" were common throughout Scotland was being

${ }^{75}$ Statistical account, vol. 7, East Kilbride, p. 414.

${ }^{76}$ Ibid., Carmunnock, p. 172.

77 Statistical account, vol. 16, Banff, p. 44.

78 Ibid., Mortlach, p. 335.

${ }^{79}$ Ibid., Banff, pp. 44-45n.

${ }^{80}$ Statistical account, vol. 17, Tarbat, p. 646, Kiltearn, p. 469.

81 Statistical account, vol. 6, Kilwinning, p. 341.

82 Statistical account, vol. 13, Auchterhouse, p. $51 \mathrm{n}$.

${ }^{83}$ Ibid., p. 5ln. This seems to contradict T. C. Smout's contention that ministers and local landowners could virtually force inoculation on local inhabitants. Smout, op. cit., note 14 above, p. 256. 


\section{Smallpox inoculation in eighteenth-century Scotland}

overly pessimistic. ${ }^{84}$ In fact, some portions of the population were abandoning their beliefs in an active Providence and

beg[an] to be sensible, that man is left, at least in many things, to the freedom of his own will, and that as a free agent, he may be instrumental in promoting his own temporal happiness, or multiplying his misfortunes. ${ }^{85}$

Consequently, they were also warming to inoculation, much to their ministers' pleasure. In Leuchars, Fife, for example, "some years ago, the people in this parish professed a religious scruple against innoculating [sic] their children. They are now come to look upon it as a religious duty to adopt the practice"; while nearby in Newburgh, "the good sense, and well directed affection of parents begin to overturn any prejudices". ${ }^{86}$ People were "fast surmounting their prejudices against inoculation" in Forfarshire, where the objection to the practice "daily losses [sic] ground". ${ }^{87}$ Even as far north as Inverness-shire, "The prejudices, entertained by the inhabitants of this parish against inoculation, were, for a long time, invincible. But the better sort, setting the example, the rest gradually followed" ${ }^{88}$

\section{THE DISTRIBUTION OF INOCULATION}

Thus, the use of inoculation was crucially dependent on smallpox mortality, access to free inoculation and religious beliefs, all of which varied geographically. As a result, inoculation was also distributed unevenly over the country, in a far more complex fashion than previous writers have appreciated. Most, including Razzell, have been content to repeat the opinion of eighteenth-century writers that levels of inoculation varied with population density - the practice was less popular in cities, where smallpox was endemic, than in rural areas which suffered periodic epidemics. ${ }^{89}$

In a few instances, its popularity differed sharply over small areas. Within Strathdon parish the procedure was firmly established in one part and neglected in another. ${ }^{90}$ Adjoining parishes also varied in their response to inoculation; in Tough there was a strong prejudice against it while the inhabitants of the neighbouring parishes of Cluny and Alford happily had their children inoculated. ${ }^{91}$ Even in areas where inoculation was generally popular, the inhabitants of a single parish, like those of Kirkmabreck, Kirkcudbrightshire, might still retain their dislike of the procedure. $^{92}$

Such striking local variations were relatively unusual, and it is possible to map levels of inoculation over Scotland. It was most frequently used in two regions-a broad band circling the west of Scotland, including the islands of Orkney, Shetland,

\footnotetext{
${ }^{84}$ Statistical account, vol. 6, Kilwinning, p. 341.

${ }^{85}$ Statistical account, vol. 8, Kilfinan, pp. 209-10n.

${ }^{86}$ Statistical account, vol. 10, Leuchars, p. 615, Newburgh, p. 664.

${ }^{87}$ Statistical account, vol. 13, Edzell, p. 217, Forfar, p. 263.

${ }^{88}$ Statistical account, vol. 17, Kilmalie, p. 117.

${ }^{89}$ Razzell, op. cit., note 2 above, pp. 70, 73.

90 Statistical account, vol. 14, Strathdon, p. 706.

91 Ibid., Tough, pp. 729-30, Cluny, p. 439, Alford, p. 405.

92 Statistical account, vol. 5, Kirkmabreck, p. 229.
} 


\section{Deborah Brunton}

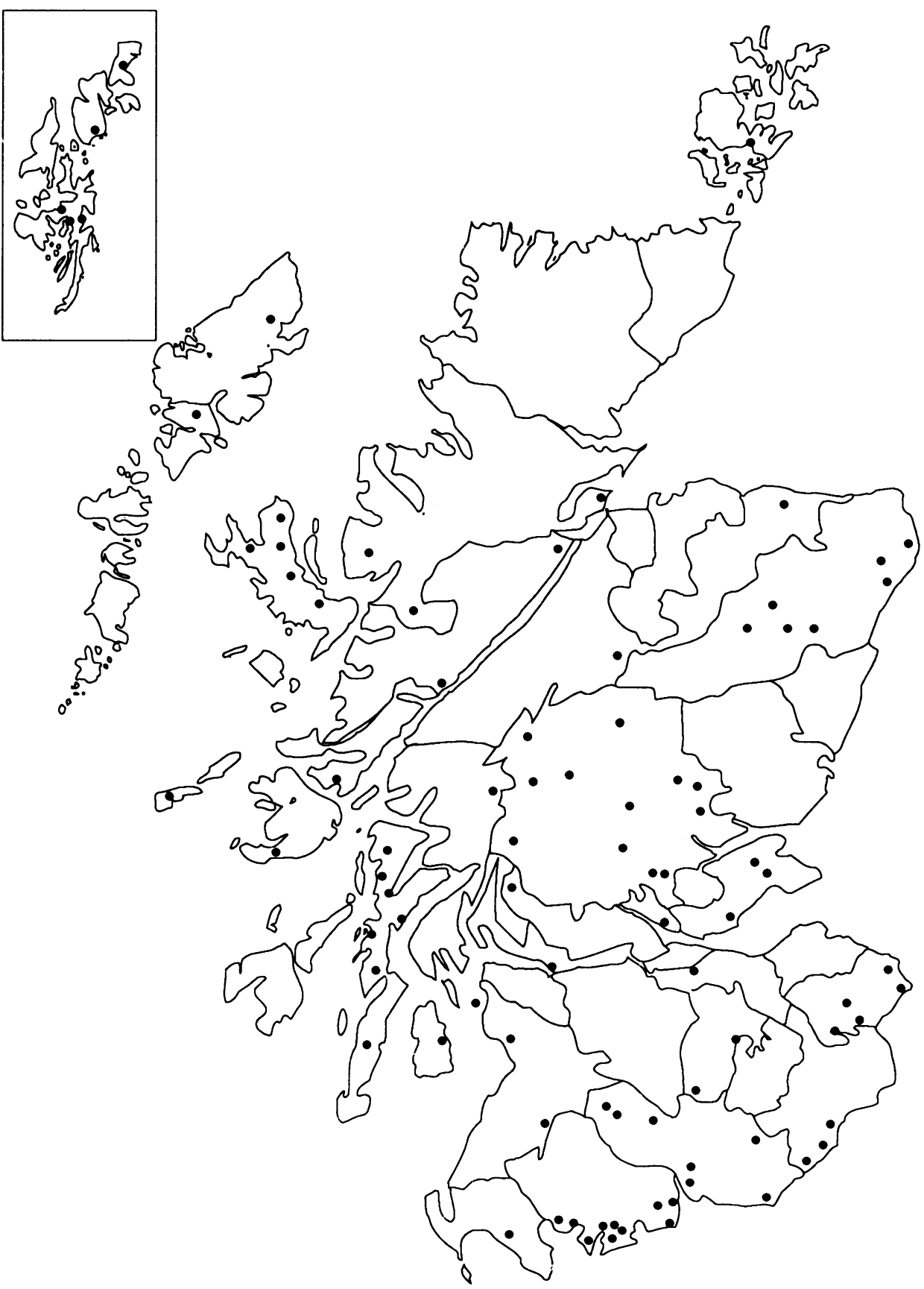

Map 2: Parishes where inoculation was popular. 


\section{Smallpox inoculation in eighteenth-century Scotland}

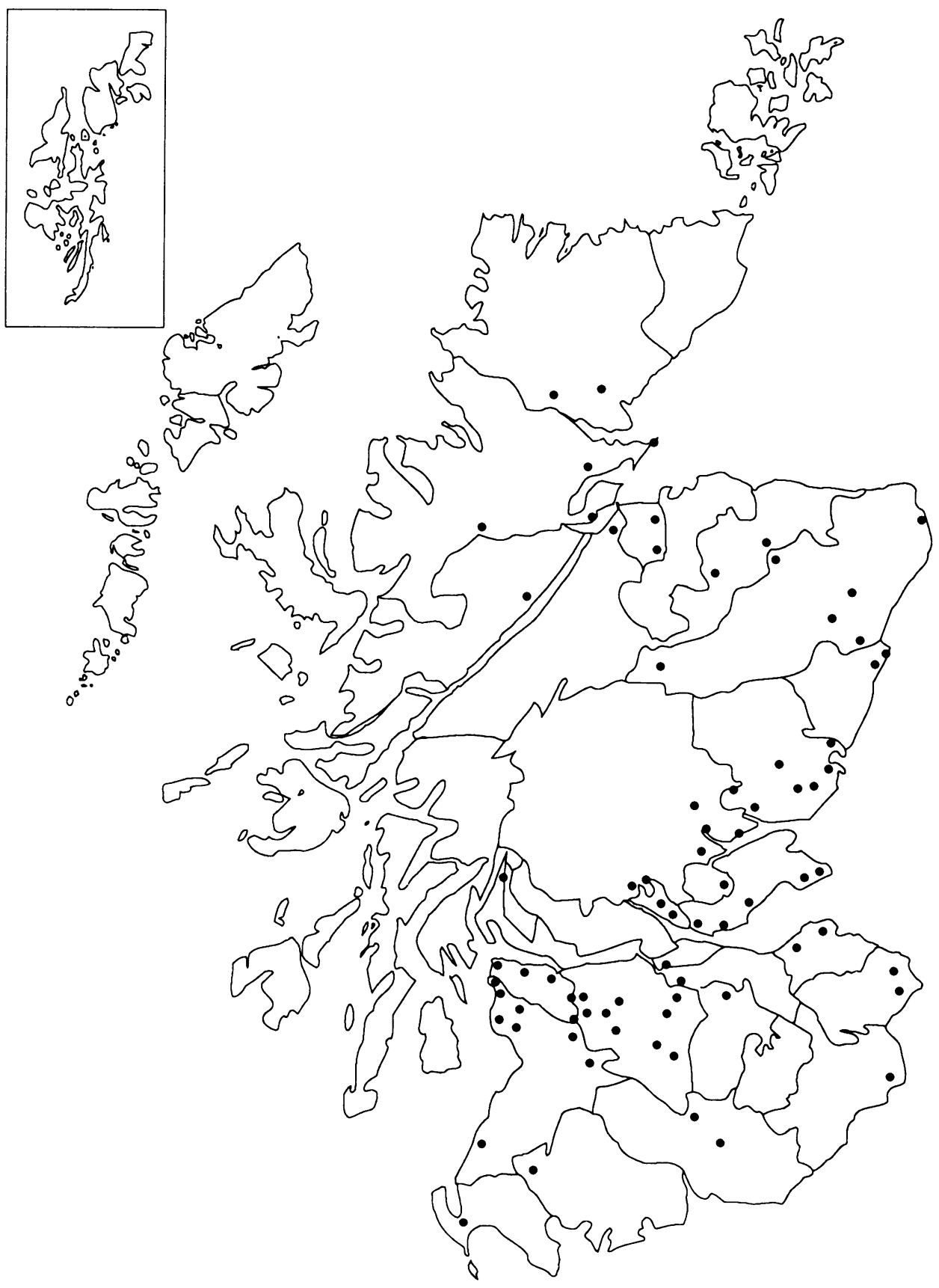

Map 3: Parishes where inoculation was unpopular. 


\section{Deborah Brunton}

the Outer and Inner Hebrides as far south as Tiree, mainland Argyllshire and parts of north Perthshire. The second area covered the southern counties of Dumfriesshire, Kirkcudbright and Wigtownshire, and parts of Berwickshire and Roxburghshire. In these regions, inoculation was described as "prevailing", "universal", and "perfectly general" in a large proportion of parishes. In Argyllshire, for example, inoculation was in general use in nine of the eleven parishes which reported on the practice. ${ }^{93}$ High levels of inoculation were recorded over large areas of Dumfriesshire, in at least a dozen parishes in Kirkcudbright and Wigtownshire, and several more in Berwick and Roxburgh. 94

These areas had a relatively long history of inoculation; in many parts the practice had "prevailed" for twenty years, and it had been used on Skye for thirty. ${ }^{95}$ During this time, any reservations about inoculation had gradually worn away and the procedure was adopted by all sections of the community; on Mid Yell inoculation was used "even by the common people", and the incumbent of Bressay proudly recorded that "the people ... submit to this operation with a degree of readiness which does them credit". 96 Consequently, a high proportion of the population was protected. In the Shetland parishes of Aithsting and Tingwall over half the total population, 600 and 900 respectively, had been inoculated, in Peebles over 1,000 inhabitants from a total of less than 2,000, while around Jedburgh roughly a third of the inhabitants had undergone the procedure. ${ }^{97}$ In the Argyllshire parish of Killean and Kilchenzie, which had a population of less than $2,000,100$ children were inoculated in one year. ${ }^{98}$

In sharp contrast inoculation was deeply unpopular in three distinct regions as a result of religious objections. The first area lay in the north-east of Scotland, covering parts of Banffshire, Nairn, Inverness-shire, and Ross and Cromarty. There, inoculation was not "relished, among the lower ranks" and was "by no means become general". ${ }^{99}$ It was so unpopular that, in an effort to encourage it, a Banffshire practitioner was driven to open

a policy of insurance for the small-pox! If a subscriber gives him two guineas for inoculating his child, the surgeon, in the event of the child's death, pays ten guineas to the parent. For every guinea subscribed, four guineas, for one half guinea, two guineas; and for a crown, one guinea. ${ }^{100}$

93 Statistical account, vol. 19, Northmavine, p. 469; vol. 8, Glassary, p. 102, Inverchaolain, p. 166, Kilbrandon and Killchattan, p. 173, Kilcalmonell and Kilberry, p. 183, Killean and Kilchenzie, p. 239, Kilmartin, p. 257, Kilninver and Kilmelfort, p. 289n, Morvern, p. 373, North Knapdale, p. 301.

94 Statistical account, vol. 4, Dornock, p. 83, Dumfries, p. 134, Kirkconnel, p. 280, Morton, p. 422, Sanquhar, p. 470, Tinwald, p. 487, and Westerkirk, p. 564; in Berwickshire, vol. 3, Earlston, p. 145, Eccles, p. 155, Greenlaw, p. 196, Castleton, p. 384, Jedburgh, p. 486, Melrose, p. 568, Southdean, p. 641. In Wigtownshire, ibid., Mochrum, p. 464, Stranraer, p. 523; in Kirkcudbrightshire, vol. 5, Anwoth, p. 3, Borgue, p. 39, Kelton, p. 162, Kirkbean, p. 174, Kirkcudbright, p. 190, Kirkmabreck, p. 229, New Abbey, p. 280, Tongland, p. 320, Twynholm, p. 349.

${ }^{95}$ Statistical account, vol. 3, Jedburgh, p. 486, Earlston, p. 145; vol. 19, Glassary, p. 102; vol. 20, Strath, p. 224, Duirinish, p. 161.

96 Statistical account, vol. 19, Mid and South Yell, p. 542; Bressay, Burra and Quarff, p. 393.

97 Ibid., Tingwall, p. 480, Aithsting and Sandsting, pp. 389-90; vol. 3, Jedburgh, p. 486, Peebles, p. 873.

98 Statistical account, vol. 8, Killean and Kilchenzie, p. 239.

99 Statistical account, vol. 16, Dyke and Moy, p. 538, Banff, p. 44.

${ }^{100}$ Ibid., Banff, p. 45n. 
It is not recorded whether any parents took up his offer, or if any benefited under the scheme.

The second region lay further south, in a belt running round the east coast of Scotland, from Aberdeenshire through Kincardineshire, Angus, south Perthshire into Kinross, Clackmannan, and Fife. Here, inoculation was "not used" in Nigg, it made "very little progress" in Banchory-Devenick, and, though it had been introduced, had not come into regular use in Marykirk. ${ }^{101}$ In Angus, "no arguments" could persuade the lower classes of Maryton to adopt the procedure. ${ }^{102}$ Religious prejudices overcame the incentive of free inoculation, and attempts to mount public inoculations failed dismally. A local landowner in Dunnichen agreed to pay for the inoculation of the poor, but though the "measure was publicly recommended in church by the minister, and privately by the whole kirk-session, yet . . only 9 or 10 children [were] inoculated". ${ }^{103}$ It was the same story in Kirkden where "In vain, the patriotic $\mathrm{Mr}$. Dempster provided, last season, an able physician and proper medicines: Though inoculation by these means, may have been got gratis, hardly one accepted the generous offer". 104

By far the strongest antipathy to inoculation was recorded in the Western Lowlands, in the counties of Ayr, Lanark, Renfrew and Dunbarton. Here the ministers' reports take on a repetitive ring; in Cathcart, inoculation had "made but small progress", in Greenock "the lower sort of people ... will not be persuaded to avail themselves of inoculation", the people of Inverkip had "an unconquerable aversion to inoculation", and when a few children were inoculated in Eaglesham in 1786, "it seemed to give pain to the people in general, that they came so well and easily through". ${ }^{105}$ Even where inoculation had gained a foothold it did not flourish; in Stonehouse, Lanarkshire, though "some have begun to inoculate: [and] In every instance where tried, it was successful; but the prejudices of the people against it are so strong, that it is not gaining ground". ${ }^{106}$ With little public confidence in the procedure, "the least accident tend[ed] to discredit" inoculation, and in Avendale, Lanarkshire, its progress was severely hampered "owing to it having proved fatal in one or two instances". ${ }^{107}$ In these areas, virtually no inoculations were performed; in West Kilbride, all efforts to introduce the practice had failed, in Kilwinning, it was practised in only two or three families, and in Symington, there had been only "two or three" instances of inoculation. ${ }^{108}$

Over the remainder of the country where religious objections were gradually diminishing, inoculation grew in popularity. In Fife, inoculation "increased" in Anstruther, "daily gains ground" in Cupar, while in Kirkcaldy and Carnock the long held "scruples" against it "seem to be subsiding". ${ }^{109}$ It was also reported to "begin to

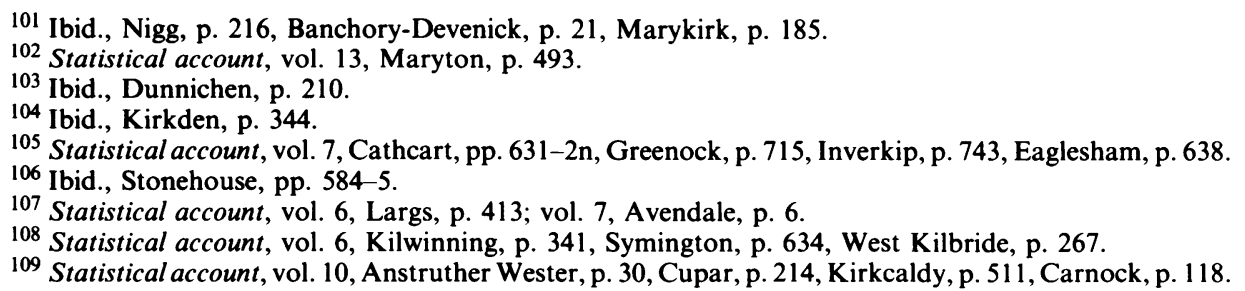




\section{Deborah Brunton}

take place among all ranks" in the parish of Culross, Perthshire, while in Kilmalie, Inverness-shire, prejudices had given way to the extent that 460 inhabitants submitted to the procedure in one year. ${ }^{110}$ In parts of Aberdeenshire, too, the practice of inoculation was "getting in" as the people "got over their prejudices". 111

Mapping levels of inoculation in this way shows the very poor fit between population density and inoculation practice. Certainly, inoculation was unpopular around the city of Glasgow, but it was equally so in two rural areas which suffered epidemic smallpox. Counties where inoculation was most frequently used did have a fairly low population density, but in the most thinly populated ones-such as Inverness-shire, Sutherland, and Ross and Cromarty-the practice was, though coming into use, not well established.

\section{CONCLUSION: THE IMPACT OF INOCULATION ON SMALLPOX MORTALITY}

There is no doubt that any measure which controlled smallpox would have a significant impact on eighteenth-century mortality levels. Smallpox was a major killer. Repeated and frequent attacks of infectious diseases such as smallpox, measles and whooping cough replaced the wars, plague and famines responsible for repeated mortality crises of the seventeenth century. In Scotland, smallpox incidence possibly increased during the eighteenth century, and, though the proportion of deaths attributed to it varied widely between parishes, in all areas it acted as a significant check on population growth. 112

It is difficult to explain exactly how inoculation consistently produced a milder form of smallpox than natural infection. ${ }^{113}$ However, throughout the eighteenth century, inoculators reported mortality rates for inoculation from around 1 in 50 in the earliest inoculations, to Daniel Sutton's famous boast that he had inoculated 40,000 and lost only 5, while natural smallpox killed 1 in 12 or 1 in $20 .^{114}$ Over the population as a whole, inoculation also controlled smallpox outbreaks. As Razzell has shown, the spread of the disease was halted if general inoculations were mounted as soon as it appeared. Regular general inoculations covering a large proportion of those susceptible reduced smallpox deaths. ${ }^{115}$

In Scotland, in those parishes where inoculation was popular, the number of smallpox deaths was reported to have decreased. In the northern islands devastating epidemics became a thing of the past; on Shetland where "formerly, the smallpox occasioned the most dreadful ravages . . . Now, hardly any suffer by this disorder". 116 On Skye, inoculation was claimed to be responsible for the "preservation of many lives" as smallpox was fatal in "very few instances", and on Mull, the "havock"

\footnotetext{
110 Statistical account, vol. 11, Culross, p. 101; vol. 17, Kilmalie, p. 117.

111 Statistical account, vol. 15, Forbes and Kearn, p. 139, Rayne, p. 480; vol. 14, Cluny, p. 439.

112 Flinn, op. cit., note 14 above, pp. 8-9.

113 For a discussion of the mechanism of inoculation, see Derrick Baxby, Jenner's smallpox vaccine. The riddle of vaccinia virus and its origin, London, Heinemann Educational Books, 1981, pp. 24-36.

114 Genevieve Miller, The adoption of inoculation for smallpox in England and France, Philadelphia, University of Pennsylvania Press, 1957, p. 118; David van Zwanenberg, 'The Suttons and the business of inoculation', Med. Hist., 1978, 22: 71-82, p. 80.

115 Razzell, op. cit., note 2 above, pp. 140-58.

116 Statistical account, vol. 19, Mid and South Yell, pp. 541-2; see also Lerwick, p. 441, Tingwall, p. 486.
} 


\section{Smallpox inoculation in eighteenth-century Scotland}

caused by smallpox was "mostly done away with". ${ }^{117}$ On the mainland, ministers also believed that inoculation had proved beneficial. The minister of Mochrum reported that "the sad ravage occasioned by the small pox is now much abated". 118 In Rosemarkie, Ross and Cromarty, the incidence of smallpox was reportedly reduced by inoculation so that "very few" children had died from the disease in the last twenty years; in Alvie, "very few die of that nauseous disorder"; in Tulliallan, the effects of smallpox were "greatly alleviated", while the minister of Weem in Perthshire stated that "small-pox generally carried off one in 7; but since inoculation has become pretty general, not 1 in 200". 119 Unfortunately, it is impossible to check these observations, as all the extant burial records which give cause of death are either from parishes where inoculation was not generally used or from those where there are no reports of its popularity.

Even where only part of the community was inoculated, it was reported to have had some effect in decreasing smallpox deaths. In several parishes the disease was described as "less destructive" as a consequence of partial inoculation. ${ }^{120}$ However, three ministers complained that this had actually increased the prevalence of smallpox. In Rayne, Aberdeenshire,

The infection is communicated from the inoculated to the children of those who still retain their old prejudices; and thus we have the smallpox raging every year in a place, where ... about 30 years ago, the distemper used to come about only once in 4 or 5 years. $^{121}$

On the island of Cumbrae, too, the minister believed that smallpox was more frequent since the introduction of inoculation. Neither minister made any mention of whether increased smallpox incidence led to a rise in the number of deaths, but their colleague at Torthorwald, Dumfriesshire, produced a table of mortality to illustrate how the number of smallpox victims had increased with inoculation. ${ }^{122}$ Such a finding perhaps should not be taken at face value for two reasons. First, inoculation was usually performed during smallpox epidemics, when the infection was already rife. Second, most of those inoculated were children, who, even if not confined indoors by the resulting illness, were unlikely to stray far beyond the confines of their own small settlement and carry the infection throughout a scattered population.

In sum, however, inoculation was simply too little practised to fulfil its potential to control smallpox. Reports of a reduction of smallpox deaths were relatively rare. Of almost 250 accounts of inoculation in the Statistical account, fewer than a quarter

117 Statistical account, vol. 20, Portree, p. 194, Snizort, p. 215, Kilfinichen and Kilviceuen, p. 284.

118 Statistical account, vol. 3, Mochrum, p. 464; also Eccles, p. 155; vol. 5, New Abbey, p. 280, Kelton, p. 162, Stranraer, p. 523. See also Eyemouth, p. 173, Mordington, p. 263, Jedburgh, p. 468, Tweedsmuir, p. 913 , Dornock, p. 83.

119 Statistical account, vol. 17, Rosemarkie, p. 599, Alvie, p. 5; vol. 11, Tulliallan, p. 616; vol. 12, Weem, p. 804. See also vol. 14, Alford, p. 405; vol. 17, Inverness, p. 83, Glensheil, p. 407; vol. 15, Forbes and Kearn, p. 139.

${ }_{120}$ Statistical account, vol. 15, Rathen, p. 472, vol. 7, New or East Kirkpatrick, p. 54; vol. 12, Comrie, p. 269 ; vol. 18 , Dornoch, p. 360.

121 Statistical account, vol. 15, Rayne, pp. 480-1.

122 Statistical account, vol. 20, Cumbrae, p. 448; vol. 4, Torthorwald, pp. 508-9. 


\section{Deborah Brunton}

actually claimed a decline in deaths, although a larger number of parishes-around one-third-reported that inoculation was popular and we can assume that it probably was having some effect on smallpox mortality. However, the overall impact of inoculation on mortality over the country was negligible. Even at the regional level-and as we have seen, inoculation practice was concentrated in two large areas-a decline in deaths is not discernible in the mortality indices from Scottish population history. Given the paucity of parish records, these indices should be treated with caution, and at best serve as a rough guide to mortality levels. Even so, if smallpox was significantly reduced, they would be expected to show at least a flattening out of mortality crises as described by Mercer. However, the figures from 1765 , when inoculation was rare, to 1800 show no reduction in mortality. In fact, in a number of areas, including the western and eastern borders, the death rates show a peak in the 1790s, when smallpox was widespread. In the far north, and 'in the Highlands and Hebrides, where inoculation had come into general use in some parishes, there is no obvious downward trend; both had high and widely fluctuating mortality. In the north east where inoculation was little practised, mortality increased over the late 1780 s and 1790 s. Ironically, the Western Lowlands, where inoculation was least popular, actually enjoyed a considerable decrease in mortality. ${ }^{123}$

The relationship between inoculation and population growth in Scotland is similarly ill defined. Razzell made a strong case for a link between the two, although more recently the connection between declining mortality and population growth has been challenged by demographers. ${ }^{124}$ In those areas where inoculation was popular, a number of ministers identified it as a cause of rising population. In Sanquhar, Dumfriesshire, for example, the minister claimed that the creation of new manufactures, "the success attending the inoculation of children and the improved mode of living and cleanliness among the people" contributed to the increased population. ${ }^{125}$ The minister of Kirkmabreck also believed that growth was due to inoculation, improvement of land and new manufactures, and these views were repeated by ministers on the islands of Skye, Tiree, Unst, and some of the Shetlands. ${ }^{126}$

It is virtually impossible to confirm these impressions. We know that the population of Scotland grew considerably between 1755 and 1801 by at least 28 per cent, and, after allowing for substantial emigration, perhaps as much as 33 per cent, from $1,265,000$ to over $1,600,000$. The details of this growth are hard to establish, but Michael Flinn has suggested that the highest rates occurred between 1760 and 1780 , declining slightly in the 1790 s. $^{127}$ This does not fit with the pattern of inoculation practice, which was still coming into use in the 1780s and at its most popular in the 1790s. At the parish level, too, its role in population growth is obscure. As a rough check on the ministers' claims that it had a positive effect, the population figures

${ }^{123}$ Flinn, op. cit., note 14 above, Appendix A, pp. 486-7.

124 E. A. Wrigley, 'The growth of population in eighteenth-century England: a conundrum resolved', Past and Present, 1983, 98: 121-50, pp. 129-34.

125 Statistical account, vol. 4, Sanquhar, p. 471.

126 Statistical account, vol. 5, Kirkmabreck, pp. 229-30; vol. 20, Duirinish, p. 161, Portree, p. 194, Snizort, p. 215 , Strath, p. 224, North Uist, p. 112.

${ }^{127}$ Flinn, op. cit., note 14 above, pp. 58, 302 and 14, 242. 


\section{Smallpox inoculation in eighteenth-century Scotland}

reported in the Statistical account were compared with those given in the 1801 census to estimate levels of growth. It was assumed that those parishes where inoculation had been adopted were unlikely to abandon the procedure and would continue to have a relatively higher level of inoculation and, therefore, a higher rate of growth than parishes where the practice was unpopular in 1790. However, no such relationship can be detected; over the period the population of some parishes where inoculation was favoured actually shrank, and in others where it was not used, population grew rapidly. Any effect of inoculation has been swamped by migration within Scotland and other factors.

A final piece of evidence that inoculation failed significantly to reduce smallpox deaths comes from nineteenth-century population figures. Scotland experienced a sharp rise in population growth rates between the first two censuses in 1801 and 1811, corresponding to the introduction of vaccination. ${ }^{128}$ Vaccination came into general use very rapidly in Scotland, helped by the provision of free immunization. In the cities, thousands were vaccinated free at vaccine institutes, hospitals and dispensaries, while in the countryside, ministers were encouraged to take up the procedure by the General Assembly of the Church of Scotland. Working with a group of Edinburgh physicians, the Church distributed a pamphlet with instructions for the procedure and promises of a free supply of vaccine. ${ }^{129}$ Vaccination was cited as a factor in population growth in the 1811 census by a significant number of ministers, particularly from counties where inoculation was unpopular. Their opinions are confirmed by Robert Watt's statistics on smallpox deaths among children in Glasgow. Up to 1801 , smallpox caused an average of 18 per cent of all deaths, but by 1810 , the rate had fallen to 4 per cent. ${ }^{130}$

Clearly, Razzell's thesis on the links between inoculation and declining mortality is not applicable to the whole of Britain. Inoculation may have been a factor in reducing death rates in southern England where there was a well-established system of public inoculation which protected a large proportion of the population. But it is a serious mistake to extrapolate from this data and to conclude that inoculation was equally popular over the whole of Britain. In Scotland, it was far from generally used. Although welcomed by the educated upper classes it still found little support among the "lower ranks" who comprised the bulk of the population. Consequently, inoculation made only a very minor contribution to declining mortality and population growth in Scotland.

\section{APPENDIX}

\section{Levels of Inoculation by Parish}

Note: I have tried to paraphrase the ministers' assessment of inoculation. "Limited use" means that the lower classes had not yet adopted the practice. Where the ministers believed smallpox was reduced by inoculation, I have assumed inoculation was popular.

128 Ibid., pp. $390-3$.

129 Address to the reverend the ministers of the Church of Scotland from the managers of the Vaccine Institute of Edinburgh, Edinburgh, George Caw, 1803.

${ }_{130}$ Flinn, op. cit., note 14 above, p. 292, Answer to sixth and seventh questions, Additional Questions to the 1811 Census, B.M. Add. MS 6897. 
Aberdeenshire

(North)

Auchindoir

Cairnie

Crimond

Cruden

Deer

Forbes and Kearn

Fyvie

Peterhead

Rathen

Rayne

(South and West)

Alford

Birse

Cluny

Crathie

Peterculter

Strathdon

Tough

Towie

Angus

Auchterhouse

Dundee

Dunnichen

Edzell

Forfar

Kettins

Kinnettles

Kirkden

Linthrathen

Logie

Maryton

Argyll

Glassary

Glenorchy and

Inishail

Inverchaolain

Kilbrandon

Kilcalmonell

Kilfinan
Killean

used -50 inoculated

"last spring"

limited - not lower

classes

little -20 inoculated

in 1792

"pretty general"

popular -100

inoculated in 1792

popular among most

of population

"not very common"

used - but "far from

general"

used by "some of the

people"

increasing use

"very general",

smallpox abated

practised a little

"begins to be general"

Kilmartin

Kilninver

North Knapdale

Morvern

Ayrshire

Ballantrae

Beith

Old Cumnock

Fenwick

Galston

Girvan

Irvine

Kilbirnie

West Kilbride

Kilmaurs

Kilwinning

Largs

Loudoun

Sorn

not practised

practised, but "not

general"

very limited use

popular

Stevenston

Straiton

Symington

Banffshire

Banff

Botriphnie

Fordyce

practised

limited use

increasingly popular

increasingly popular

practised, but not

general

limited use

limited use

limited use

limited use

limited use

general

practised

popular, not universal

general

"almost universal"

limited - not lower

ranks

Forglen

Mortlach

St. Fergus

Berwickshire

Chirnside

Cockburnspath

Coldingham

Earlston

Eccles

Eyemouth

Greenlaw

Mordington

Caithness

Canisbay general -100

inoculated last year

"pretty general"

popular

popular - smallpox

deaths reduced

popular

used, but not popular

limited use

practised - prejudice

declining

very limited use

practised -500

inoculated in 12 years

limited use

increasingly practised

practised

not practised

used, not general

not used

limited use

practice increasing

practised, not general

practised

general, "even among

lower orders"

very rare - two or

three instances

practised, not general

not practised

popular - smallpox

"abated"

practised

limited use

general

limited use

practised, not general

limited use

general

general

popular

popular

popular

practised, not general

N.B. General inoculation performed throughout the county 


\section{Smallpox inoculation in eighteenth-century Scotland}

Clackmannanshire

Clackmannan

Tillicoultry

Dumfriesshire

Applegarth

Canonbie
Dornock
Dumfries
Hutton and Corrie
Kirkconnel
Kirkpatrick-Juxta
Morton
Sanquhar
Tinwald
Torthorwold
Westerkirk

Dunbartonshire

Arrochar

East Kilpatrick

Old Kilpatrick

Fife

Aberdour

Anstruther

Carnock

Crail

Creich

Cupar

Dalgety

Inverkeithing

Kilconquhar

Kirkcaldy

Largo

Leuchars

Markinch

Newburgh

St. Monans

Scoonie

Wemyss

Inverness-shire

Alvie

Inverness

Kilmalie limited use
limited use

limited - prejudices
diminishing
practised
"generally practised"
popular
practised, but "not
commonly"
general
limited use
"pretty general"
popular
"generally adopted"
practised
"very general"

practised - not

popular

commonly practised

general

"frequently practised" practised, and increasing

practised, still some

prejudice

limited use

popular

practice increasing

very limited use

limited use

very limited use

practised

"generally introduced"

popular

limited use

practised

practised, and

increasing

practised

prejudice against

inoculation

popular

popular

popular -460

inoculated in one year $\begin{array}{ll}\text { Petty } & \text { limited use } \\ \text { Urquart } & \text { limited use }\end{array}$

\section{Kincardine}

Banchory-Devenick very limited

Marykirk

Nigg

practised, not general

not used

Kinross

Cleish

Portmoak

practised, not popular not used

Kirkcudbright

Anwoth general

Borgue general

Kelton popular

Kirkbean inoculation "frequent"

Kirkcudbright general

Kirkgunzeon practised

Kirkmabreck popular

Kirkpatrick-Irongray practised

Monigaff limited use

New Abbey popular - smallpox

Tongland

Twynholm

\section{Lanarkshire}

Avendale

Carmunnock

Carnwarth

"abated"

popular - used by all

ranks

inoculation "almost

universal”

Dalziel

practised, not general

not practised

limited use but

increasing

not practised

Barony of Glasgow

Hamilton

practised, but far from

general

East Kilbride

limited use

not practised

limited - 20-30

inoculated in 1787 ,

1792

East Monkland practised, not general

Old Monkland practised

Pettinain

Stonehouse

Wiston and

Roberton

practised, not yet

general

limited use

"little practised"

Lothians

West Calder inoculation "rare"

Inveresk

practised, but not

general 


\begin{tabular}{|c|c|c|c|}
\hline $\begin{array}{l}\text { Garvald and Baro } \\
\text { Tranent }\end{array}$ & $\begin{array}{l}\text { practised, not general } \\
\text { limited - inoculation }\end{array}$ & $\begin{array}{l}\text { Blairgowrie } \\
\text { Callander }\end{array}$ & $\begin{array}{l}\text { popular } \\
\text { practised }\end{array}$ \\
\hline Kirkliston & $\begin{array}{l}\text { "little used" } \\
\text { popular nearly half } \\
\text { inoculated }\end{array}$ & $\begin{array}{l}\text { Clunie } \\
\text { Comrie } \\
\text { Dull }\end{array}$ & $\begin{array}{l}\text { practised, increasing } \\
\text { general } \\
\text { "very common" }\end{array}$ \\
\hline Queensferry & practised & Dunblane & limited use \\
\hline Whitburn & practised "very little" & Fortingall & universally practised \\
\hline Athelstaneford & limited use & Killin & $\begin{array}{l}\text { popular - smallpox } \\
\text { reduced }\end{array}$ \\
\hline Morayshire & & Kilmadock & use \\
\hline $\begin{array}{l}\text { Abernethy and } \\
\text { Kincardine }\end{array}$ & practised, not general & $\begin{array}{l}\text { Kirkmichael } \\
\text { Logierait }\end{array}$ & $\begin{array}{l}\text { practised, not general } \\
\text { popular - smallpox }\end{array}$ \\
\hline Dallas & $\begin{array}{l}\text { popular, smallpox } \\
\text { reduced }\end{array}$ & Monzie & popular - smallpox \\
\hline Dyke and Moy & practised, not general & Moulin & $\begin{array}{l}\text { reduced } \\
\text { popular }\end{array}$ \\
\hline $\begin{array}{l}\text { Nairnshire } \\
\text { Ardclach } \\
\text { Auldearn }\end{array}$ & $\begin{array}{l}\text { limited use } \\
\text { not used }\end{array}$ & $\begin{array}{l}\text { Muthill } \\
\text { Weem }\end{array}$ & $\begin{array}{l}\text { "very common" } \\
\text { general }\end{array}$ \\
\hline & & Renfrewshire & \\
\hline Orkne & & Cat & d use \\
\hline Kirkwall and St Ola & prac & Eaglesham & use \\
\hline Orphir & practised & $\begin{array}{l}\text { Erskine } \\
\text { Greenock }\end{array}$ & $\begin{array}{l}\text { limited use } \\
\text { limited use }\end{array}$ \\
\hline $\begin{array}{l}\text { Peeblesshire } \\
\text { Innerleithen }\end{array}$ & pract & $\begin{array}{l}\text { Inverkip } \\
\text { Mearns }\end{array}$ & $\begin{array}{l}\text { very limited use } \\
\text { practised and }\end{array}$ \\
\hline Newlands & $\begin{array}{l}\text { increasing } \\
\text { practised, some } \\
\text { prejudices }\end{array}$ & Renfrew & $\begin{array}{l}\text { Sing } \\
\text { d use }\end{array}$ \\
\hline Peebles & general & Ross and Cromarty & \\
\hline $\begin{array}{l}\text { Traquair } \\
\text { Tweedsmuir }\end{array}$ & $\begin{array}{l}\text { practised } \\
\text { popular - smallpox }\end{array}$ & Applecross & $\begin{array}{l}\text { popular, recently } \\
\text { adopted }\end{array}$ \\
\hline & red & $\begin{array}{l}\text { Cromarty } \\
\text { Dingwall }\end{array}$ & $\begin{array}{l}\text { practised } \\
\text { practised, recently }\end{array}$ \\
\hline $\begin{array}{l}\text { Perthshire } \\
\text { (South and East) }\end{array}$ & & Gle & ge \\
\hline Abernethy & prac & $\begin{array}{l}\text { r Easter } \\
\text { r Wester }\end{array}$ & $\begin{array}{l}\text { ed } \\
\text { use }\end{array}$ \\
\hline $\begin{array}{l}\text { Abernyte } \\
\text { Cargill }\end{array}$ & $\begin{array}{l}\text { prac } \\
\text { popl }\end{array}$ & Kiltearn & limited use \\
\hline Coupar Angus & limited us & Logie Easter & practised, not general \\
\hline Culross & $\begin{array}{l}\text { practised and } \\
\text { increasing }\end{array}$ & markie & $\begin{array}{l}\text { ar } \\
\text { d use }\end{array}$ \\
\hline Dron & limit & Urray & limited used \\
\hline Inchture & & & \\
\hline Kinnoul & ed, not & Ros & \\
\hline Longforgan & & & ed, not general \\
\hline Scon & limit & $\mathrm{Ca}$ & \\
\hline Tulliallan & $\begin{array}{l}\text { popular - smallpox } \\
\text { alleviated }\end{array}$ & $\begin{array}{l}\text { Jedburgh } \\
\text { Melrose }\end{array}$ & $\begin{array}{l}\text { general } \\
\text { practised, and } \\
\text { increasing }\end{array}$ \\
\hline & $\begin{array}{l}\text { practised, adopted } \\
1786 / 7\end{array}$ & $\begin{array}{l}\text { Morebattle } \\
\text { Roxburgh }\end{array}$ & $\begin{array}{l}\text { "not much" practised } \\
\text { practised }\end{array}$ \\
\hline Black & tised & Southdean & "almost universal" \\
\hline
\end{tabular}


Smallpox inoculation in eighteenth-century Scotland

Selkirkshire
Galashiels

Aithsting and

Sandsting

Bressay, Burra and

Quarff

Lerwick

Northmavine

Tingwall

Unst

Walls and Sandness

Mid and South Yell

\section{Stirlingshire \\ Baldernock \\ Bothkennar \\ Buchanan \\ Gargunnock}

Kilsyth

Kippen

Sutherland

Assynt

Creich

practised and
increasing

general

practised and popular

general among all

ranks

"perfectly general"

general

general - population

increase

practised

general - population

increase

limited use

practised, but, "far

from general"

practised

practised, still some

prejudice

practised

practised

practised, not general

"scarce practised"
Dornock

Durness

Golspie

Rogart

Tongue

Western Isles

Stornoway

Harris

North Uist

Duirinish (Skye)

Kilmuir (Skye)

Portree (Skye)

Snizort (Skye)

Strath (Skye)

Tiree

Kilfinichen (Mull)

Lismore

Jura

Cumbrae

Arran

Wigtownshire

Mochrum

Stranraer practised

practised

practised

"little inoculation"

practised

practised

general

general - population

increase

general - population

increase

universal

universal

general - population

increase

general - population

increase

general - population

increase

popular

practised

limited use

popular

popular

popular - smallpox

"abated"

"frequent" 